Article Type: Research Paper

\title{
Islamic Philanthropy Empowerment Fund in Social Economic Affairs
}

\author{
Hanan Sabila ${ }^{1}$ and Endah Saptutyningsih ${ }^{1}$
}

\section{要}

\section{AFFILIATION: \\ ${ }^{1}$ Department of Economics, Faculty of Economics and Business, Universitas Muhammadiyah Yogyakarta, Yogyakarta, Indonesia. \\ *CORRESPONDENCE: \\ endahsaptuty@umy.ac.id}

THIS ARTICLE IS AVALILABLE IN:

http://journal.umy.ac.id/index.php/jerss

DOI: $10.18196 /$ jerss.040115

\section{CITATION:}

Sabila, H., \& Saptutyningsih, E. (2020). Islamic Philanthropy Empowerment Fund in Social Economic Affairs. Journal of Economics Research and Social Sciences, 4(1), 1-16.

\begin{abstract}
The development of Islamic Philanthropy funds raises many questions about its use, especially the use directed at productive use. Zakat management authorities, including LAZISMU, began to develop the use of philanthropic funds in the socio-economic sector for the Empowerment Programme. Based on the level of operation of these funds for successful programs, the Yogyakarta Regional Leaders are classified as the most developed, mainly in the Sleman Regency area. There will be many findings in this study regarding Mustahik and Amil's views on the economic empowerment system implemented by LAZISMU Regional Leader of Muhammadiyah (Pimpinan Daerah Muhammadiyah) Sleman, beginning with Empowerment Indicators, Changes in Mustahik Economic Conditions and Utilization Effectiveness using statistical methods as instruments explain the results. In this study, most of these things show significant results based on the Mustahik's point of view.

Keywords: Philanthropy Fund; Institute of Islamic Philanthropy; Utilization; Empowerment Program; Social Economy.
\end{abstract}

\section{Introduction}

According to the Badan Pusat Statistik, the poverty profile in Indonesia as of September 2016 showed a decline, which was originally 28,01 people $(10,86$ percent) in March 2016 , down to 27,76 million people $(10,70 \%)$ by 0,25 million in September 2016. The poverty profile in urban areas in Java shows 7,04 poor people $(7.74 \%)$ and as many as 7.79 poor people in rural areas $(13.94 \%)$ in Java, which is the island with the most population that describes different things about the profile of the Indonesian population. When Java's poor population totaled 14,84 million people $(14,72 \%)$, this figure shows that half of Indonesia's poor population is on this island.

Poverty, besides scarcity, growth, unemployment, inequality, and others, is one of the crucial problems in the economy. Impacts caused by poverty are also of different kinds, ranging from economic problems such as unemployment and difficult economic growth, and even poverty is one of the factors that causes social problems such as criminal acts and other moral crises.

Economic and social problems such as poverty always provide answers from all walks of life, empathy for a social problem is not always carried out by a country's government, but all those who are moved often want to play a role in solving social problems, economic problems triggering the answer of all to take part in the solution of social problems and the 
development of a collective community force with a generous mission.

This community collection is often said to be the third part of structuring a country's development after the government and private sectors, while several studies have recently highlighted the role, management and authority of Islamic philanthropic institutions in the organization of charitable funds. This institution continues to develop innovations and launch various collection programs up to the use of philanthropic funds. Philanthropy comes from the definition of philanthropy: Philos (love) and Anthropos (human). Then in the concept of philanthropy practice, there is the practice of voluntarily giving, serving, and associations (associations) to help other needy parties. Allien Shaw emphasized that philanthropy is not merely charity, but empowerment that has a long-term impact (Latief, 2010).

The role of Islamic philanthropic institutions has indeed increased in the last ten years, despite the debate about who is entitled to collect and allocate funds for Zakat, Sadaqah, Waqf, and Hibah (ZISWAH) continues to burst, it can be seen with various institutions that have begun to emerge and offer different facilities to philanthropists who are kind enough to set aside their assets and then this institution can distribute to groups of people entitled to those funds. The potential funds raised by Islamic philanthropic institutions can be attributed to the majority of Indonesia's Muslim population, the obligation to pay zakat and religious advice to share with each other as psychological triggers for people who then want to share with others, eventually, the muzakki (zakat payers) who would give Amil his generous funds.

Looking back on the authority of institutions which have the right to collect and distribute these funds is not normally limited, then Islamic organizations in Indonesia also have the right to play a role in this matter so that many Islamic philanthropic institutions appear as a representation of the role of Islamic mass organizations in the field of philanthropy. Muhammadiyah, one of Indonesia's largest Islamic organizations, has also given rise to an independent philanthropic institution called the Muhammadiyah Amil Zakat Institute (Lembaga Amil Zakat Muhammadiyah, LAZISMU). Since its inception, this institution has continued to foster public trust by demonstrating the credibility of this institution in collecting and distributing the charity funds under the contract. Islamic jurisprudence, with the distribution of funds from Zakat, Infaq, and Sadaqah (ZIS) accompanied by a mentoring program as a model for empowerment, LAZISMU continues to innovate in programs to be used.

The absorption of charity funds by zakat institutions is very potential, can be described by recording a variety of other Muhammadiyah activities, then there is the potential for zakat or other philanthropic funds collected by LAZISMU in those activities. One example is the philanthropy capability that could be gained from the Muhammadiyah Charitable Enterprises (Amal Usaha Muhammadiyah, AUM) activities. The institutions that are included in the AUM are schools and hospitals. If AUM submits the obligation of zakat and or other philanthropic funds to LAZISMU, it will become an important potential because the increasing amount of AUM and spread in various regions makes the potential of Islamic philanthropic funds that may be collected by LAZISMU. 
According to survey data from other studies in 11 major cities in Indonesia, the acquisition of alms by muzaki or donor identities is still dominated by Muhammadiyah residents, with $94 \%$ of total and $6 \%$ of non-Muhammadiyah resident donors in 2015 alone (LAZISMU, EPI UMY, LP3 M UMY, 2015).

Table 1 Potential Philanthropy of Muhammadiyah Residents in 11 Cities in Indonesia in 2015

\begin{tabular}{lccr|}
\hline $\begin{array}{c}\text { Monthly Resident Earnings } \\
\text { Group }\end{array}$ & \multicolumn{2}{c|}{$\begin{array}{c}\text { Muhammadiyah Citizens' } \\
\text { Estimation } \\
\text { Amount (People) }\end{array}$} & Total Potential (Rp) \\
\hline Kurang dari 3.000.000 & 30.8 & 9240 & 1.011 .780 .000 \\
$3.000 .000-6.000 .000$ & 52.1 & 15630 & 2.422 .650 .000 \\
$6.000 .000-12.000 .000$ & 14.1 & 4230 & 9.425 .497 .500 \\
$12.000 .000-15.000 .000$ & 1.2 & 360 & 180.000 .000 \\
Diatas 15.000.000 & 1.8 & 540 & 228.690 .000 \\
Potential monthly Philanthropy Funds & & 13.268 .617 .500 \\
Potential Philanthropy Funds per year & & & 159.223 .410 .00 \\
\hline
\end{tabular}

Source: LAZISMU, EPI UMY, LP3M UMY (2015)

In the same survey at the end of the report, it was concluded that the overall potential previously grouped between Muhammadiyah Citizens ' Potentials and Muhammadiyah Charitable Enterprises, whose real potential was very large and could be synergized with LAZISMU, annual gain if the two potentials add up to a value of 500 billion rupiahs, which could be summarized as very large.

Most philanthropic institutions have not yet distributed charitable funds obtained for the socio-economic sector, among others, the most frequently encountered are in the field of education although it is beneficial and supports the right to obtain a proper education but the effect of the velocity of money is too far and is intervening towards the purpose of fund productivity managed charity. Subsequently, providing cash assistance to people who are still below the poverty line so that the productivity of the funds is the same as the money received will be disposable income, is not to blame, but there are still ways to help by not "just" support, including additional productive capitalbased programs accompanied by education and different advocacy methods.

Islam believes that money is something that needs to be flowed (flow concept), meaning that money does not belong to the rights of all, but that money must be channeled to 8 ashnaf, who need more money to be managed in productive activities. According to Western scientist Irving Fisher, the concept of accelerating money has the same concept of flow as that which develops Islamic economic doctrine about exploring the nature of money.

The Zakat distribution system, which is one of the ummah's means of economic empowerment, can be classified into two; consumptively and productively. Consumptive means zakat is allocated directly to mustahik to be used or not developed for consumption to obtain productivity from ZIS funds. While zakat assets distributed productively mean mustahik does not accept zakat assets that are used directly for 
consumption (disposable income) but must first be sought for use in the real sector, both by mustahik himself and by amil institutions (Mubasirun, 2013).

In view of the fact that ZIS is not only used as a disposable income for the beneficiaries, LAZISMU and several Islamic philanthropic institutions convert it into community empowerment programs and their advocacy to make ZIS funds more productive and indirectly depleted with minimal benefits when distributed. The empowerment program thus becomes more creative from year to year and more essential for the purpose of channeling ZIS funds themselves, namely for productive interests, so that people are free from poverty.

Community empowerment can be said as an effort to help the community develop its capacity so that they can overcome the problems and take independent decisions. Therefore, community empowerment typically aims at building strength and capacity of community institutions so that they can handle themselves independently on the basis of the community's needs and face challenges in the future (Abidin, 2013).

LAZISMU's economic empowerment programs are: a) Agriculture or Revived Farmers, b) Social Micro Finance, c) YES Program, d) Empowered Women. The four economic empowerment programs are implemented in accordance with the environmental potential of the goal of empowerment itself, which was previously reviewed by Amil, who plays a part in advocating both natural and human resources, hoping that the program will be able to run on target and achieve the expected results to be maximized. The LAZISMU branch itself has spread in various regions in Indonesia to provide facilities in gathering from muzakki and allocating ZIS funds in these areas, especially in areas that have potential and become the basis of the Muhammadiyah movement because LAZISMU is an Islamic philanthropic institution affiliated with Muhammadiyah. Muhammadiyah residents put their trust in charity funds and tend to LAZISMU. One of the bases of the Muhammadiyah movement that has the potential to absorb high ZIS funds is Yogyakarta, the special potential of LAZISMU is very obvious in Yogyakarta because it is one of the largest bases of Muhammadiyah, considering that LAZISMU's main potential is to collect in advance from Muhammadiyah Residents and Muhammadiya Charitable Enterprises (AUM). AUM in Yogyakarta is far more advanced than AUM in other areas, Muhammadiyah residents whose population is quite large in Yogyakarta increasingly show the potential for obtaining philanthropic funds raised by LAZISMU.

At the level of the Muhammadiyah Branch (Pimpinan Ranting / Cabang Muhammadiyah, PRM/PCM) and Muhammadiyah Regional Leadership (PDM), the decentralization system implemented in Yogyakarta is concerned with providing empowerment to the surrounding areas by the Muhammadiyah Regional Leadership (Pimpinan Wilayah Muhammadiyah, PWM). This makes it not only easy to monitor revolving funds given to the community but also shows LAZISMU as an amil who has the concept of professional empowerment and gives maximum attention to the empowerment program of philanthropic funds. 
LAZISMU PDM Sleman is one example of Islamic philanthropic institutions providing assistance in the empowerment of mustahik, for example PCM Sleman, ZIS funds collected by LAZISMU are partly allocated to Mustahik empowerment programs in the development of animal husbandry, multiple participants will receive productive fund allocations to goats, Participants will then care for and raise a pair of goats given to program participants until the participants are able to independently grow goat farms, Once the participants feel they can be independent, the participants must return the equivalent of a pair of goats given by LAZISMU as capital and if, after independence, it is difficult for the participants to return to the livestock business, LAZISMU will again assist in the provision of livestock as capital and the participants have the right to it.

Findings from one of the studies (Kholis, et al., 2014) with 16 case studies of BAZ and LAZ in Yogyakarta that each Zakat Management Organization (Organisasi Pengelola Zakat, OPZ) in Yogyakarta implements internal organizational standards, fundraising strategies, management and distribution, and supervisory and transparency patterns with different mechanisms and capacity of each institution. In general, the BAZ and LAZ affiliated with an institution tend to rely on wage deductions in the collection of zakat funds, while the more independent LAZ tends to create programs and accountability to attract muzakki. As far as distribution and utilization management is concerned, BAZ and LAZ distribute zakat funds for the poor, student scholarships, training, natural disaster victims, productive activities, and qardul hasan loans or permanent revolving capital. With a variety of different models of empowerment, there will be many analyzes that can be established as different models decide the concepts of Islamic economics that need to be examined in their application to society and the impacts that can be provided. The period of time out of the poverty trap by earning a constant income is 2,72 years before the distribution of productive zakat, but after the distribution of productive zakat the time needed to release the impotence of the poverty line changes to 1,51 years (Rakhmawati \& Soeratno, 2014).

According to Meylani (2009) Mustahik business income using capital from the Ikhtiar Program and work activities and the number of dependents have a significant effect on per capita Mustahik income. With the existence of productive zakat based UMKM among others have an impact on increasing business income, increasing family income, and increasing knowledge, and skills (Rahman, 2017). Managing productive zakat funds will improve the economy and will have an impact on improving mustahik welfare (Ridwan, 2013).

\section{Research Method}

\section{Study Site}

The object of research in this study was conducted in the area of Sleman Regency, Yogyakarta, the research was submitted to LAZISMU Regional Leadership of Muhammadiyah Sleman. While the research subjects in this study are mustahik recipients of Islamic philanthropic funds allocated for empowerment in the socio- 
economic program or can be said as a participant in community empowerment programs in the socio-economic field carried out by LAZISMU PDM Sleman.

\section{Survey Design and Administration}

The data in this study consisted of two types, namely primary data, field data obtained using data collection methods through in-depth interviews with mustahik and program implementers, village community leaders, and the management of LAZISMU PDM Sleman. Secondary data are data obtained from LAZISMU PDM Sleman in the form of documents concerning the procedures for community empowerment programs in the economic field, as well as a variety of literature in the form of books, scientific journals, newspapers, the internet, and others.

The sampling technique in this study used all population survey results as research respondents. The population obtained is the Mustahik on the advice of the Research Object informant namely the Chairman of the LAZISMU Assembly PDM Sleman and is expected to be able to represent the conditions in the field objectively. On the basis of the non-probability method with convenience sampling, the sampling does not have to be proportional to the population and sample selection in accordance with the preferences of the researcher. The community empowerment program in the socioeconomic sector carried out by LAZISMU PDM Sleman has not been conducted at all levels of PCM, according to information from the Chairperson of the LAZISMU Assembly PDM Sleman, the program has only been implemented at 6 PCM and the number of mustahik participating in the program has not been optimal. Both are due to the smallest allocation of funds for this program compared to the allocation of funds over the past four years for 4 other programs (Education, Da'wah, Social and Emergency Programs such as Disaster Management). Thirty samples were therefore taken as respondents in this research, who were considered capable of representing various symptoms that could answer some of the questions that had to be revealed in this study.

\section{Analysis Method}

To analyze the impact and effectiveness of the empowerment model, the data collected will be analyzed through a quantitative approach. Testing through qualitative analysis is used to measure the impact of the Islamic Philanthropy Fund Empowerment Program in the field of Social Economy on mustahik in the LAZISMU PDM Sleman target area on economic mustahik on three aspects, namely a) descriptive analysis of economic empowerment indicators with Likert Scale scoring, this analysis often used to measure a person's attitudes, opinions, and points of view about a thing. The Likert scale will be used as a measure of evaluation of community empowerment programs in the socioeconomic field based on Islamic philanthropic funds conducted by LAZISMU PWM Yogyakarta at the Sleman PDM level. In accordance with the responses of the mustahik based on indicators of the process of community empowerment to the theories that have been explained previously. The number of each indicator of empowerment 
becomes a score collectively from the value of the questions raised for each indicator with the following score categories:

Table 2 Category score

\begin{tabular}{ccc}
\hline Scor & Conversion Formula & Category \\
\hline 1 & $\mathrm{X}>\mathrm{Mi}+1\left(\mathrm{SD}_{\mathrm{i}}\right)$ & High \\
2 & $\mathrm{Mi}-1\left(\mathrm{SD}_{\mathrm{i}}\right) \leq \mathrm{X} \leq \mathrm{Mi}+1\left(\mathrm{SD}_{1}\right)$ & Low \\
3 & $\mathrm{X} \leq \mathrm{Mi}-1\left(\mathrm{SD}_{1}\right)$ & Medium \\
\hline
\end{tabular}

Source: Azwar, 2012

Note that $\mathrm{X}$ is the total score; $\mathrm{SDi}$ is the ideal standard deviation, 1/6 (maximum score ideal minimum score); $\mathrm{Mi}$ is the ideal mean, $1 / 2$ (maximum score + ideal minimum score) b) Analysis of the benefits of the economic empowerment program implemented by LAZISMU PDM Sleman by comparing the data obtained from the respondents The data referred to are certain conditions which occur in Mustahik before and after the program empowerment. This statistical technique is used to test the comparative hypothesis of two samples that are correlated when the data is nominal/discrete. Study designs usually come in "before-after" form. Therefore, the study hypothesis is a comparison of values before and after treatment (Sugiyono, 2001). The Mc Nemar test has a distribution of Chi-Square (x2), so the formula used to test hypotheses is the Chi-Square Formula. The Mc Nemar check function follows with the theory Chi-Square:

$$
x^{2}=\sum_{i=1}^{k} \frac{\left(f_{0}-f_{h}\right)^{2}}{f_{h}}
$$

Where:

$f_{0}=$ Many Frequencies are observed in the to category 1

$f_{1}=$ Many frequencies are expected below $\mathrm{HO}$ in the to category I

The Chi-Square formula can be simplified in the significance test with respect to $A$ and $D$ :

$$
\begin{gathered}
X^{2}=\frac{(A+D)^{2}}{A+D} \\
X^{2}=\sum_{i=1}^{k} \frac{\left(f_{0}-f_{h}\right)^{2}}{f_{h}}=\frac{\left(A-\frac{A+D}{2}\right)^{2}}{\frac{A+D}{2}}+\frac{\left(D-\frac{A+D}{2}\right)^{2}}{\frac{A+D}{2}}
\end{gathered}
$$

According to Yates (1934) in Sugiyono (2001) (the formula would be better with the existence of ' continuity correction: i.e. reduction by value 1 . Continuity correction is normally distributed data, since it is well known that normally distributed data is a continuum. 


$$
X^{2}=\frac{(|A+D|-1)^{2}}{A+D} \text { with } d k=1
$$

The instrument for measuring changes in economic conditions mustahik uses the nonparametric statistical test Wilcoxon Matched Pairs Test (related to two-sample tests). That technique is a sign test refinement. If the test does not take into consideration the sign of the difference in the value of the number between positive and negative, while this test is calculated. As in the test for signs, this technique is used to test the significance of two samples' correlative hypothesis. If the sample is greater than 25 , the distribution is near normal. The formula Z (Sugiyono, 2010) is therefore used as follows:

$$
z=\frac{T-\mu_{T}}{\sigma_{T}}=\frac{T-\frac{n(n-1)}{4}}{\sqrt{\frac{n(n-1)(2 n+1)}{24}}}
$$

With the description $\mu$ is the mean (arithmetic mean); $T$ is the number of levels/ranking; and $\mathrm{n}$ is the number of samples. For the test base used the T-test, $\mathrm{HO}$ is accepted if $\mathrm{T} \geqslant$ $\mathrm{T} \alpha$ and $\mathrm{HO}$ is rejected if $\mathrm{T}<\mathrm{T}$ a (Djawanto, 2003). The difference between $\mathrm{n} 1$ and $\mathrm{n} 2$ is important if $\mathrm{Z}$ arithmetic $<$ table then the difference between $\mathrm{n} 1$ and $\mathrm{n} 2$ is not significant (Martono, 2010). In this study, quantitative processing was done using the SPSS program, for efficacy and avoidance of human error.

\begin{tabular}{|c|c|}
\hline Income & $\begin{array}{l}\text { Income is an indicator of changes in economic conditions, then } \\
\text { increases or decreases }\end{array}$ \\
\hline $\begin{array}{l}\text { Transfer of } \\
\text { knowledge } \\
\text { and skills }\end{array}$ & $\begin{array}{l}\text { The process of transferring knowledge and skills, characterized by } \\
\text { external activities (amil) developing internal capacity (mustahik) in } \\
\text { external research activities, is defined as the role of amil in the internal } \\
\text { capacity building efforts, namely mustahik and it is supposed to be an } \\
\text { infusion of efforts to develop capabilities, abilities, expertise and } \\
\text { specific dimensions of power held by internal parties, namely the } \\
\text { Mustahik. }\end{array}$ \\
\hline Service & $\begin{array}{l}\text { Mustahik requires services that each party provides without any aspect } \\
\text { of exclusivity for certain parties or even marginalizes other parties, } \\
\text { services are available to anyone who is categorized as naff and follows } \\
\text { the protocol as a participant (mustahik). }\end{array}$ \\
\hline $\begin{array}{l}\text { Supervision } \\
\text { over Amil }\end{array}$ & $\begin{array}{l}\text { Supervision is an activity aimed at monitoring, evaluating and } \\
\text { determining activities that need to be done normatively. }\end{array}$ \\
\hline $\begin{array}{l}\text { Community } \\
\text { and network } \\
\text { based }\end{array}$ & $\begin{array}{l}\text { The program implemented is a system that gathers many people and } \\
\text { develops networks between individuals and various parties outside the } \\
\text { group. }\end{array}$ \\
\hline $\begin{array}{l}\text { Independence } \\
\text { of mustahik in } \\
\text { the business } \\
\text { sector }\end{array}$ & $\begin{array}{l}\text { Mustahik can make decisions and manage enterprises with its own } \\
\text { capabilities. }\end{array}$ \\
\hline
\end{tabular}

\section{Operational Definition}




\section{Result and Discussion}

Based on the data collected by the authors from the results of field research on respondents, the characteristics of respondents based on majority sex are men with a total of 23 out of 30 persons or a percentage of $76,6 \%$ and participants with a female gender of less than 7 out of 30 persons or $23,3 \%$. Most respondents were between the ages of 40 and 50 with 11 out of 30 respondents or $36,7 \%$. The composition of participants in the economic empowerment program implemented by LAZISMU is dominated by age groups over 40 because it is less relevant if Islamic philanthropy funds are allocated more to younger age groups, given that physical abilities and opportunities to develop are wider. From the data collection results, it is known that the majority of respondents have graduated from elementary school, i.e. the SMP / SLTP and SMA / SMK / SLTA groups, each with a frequency of 12 persons or a percentage of $40 \%$, and the Diploma / Bachelor / equivalent level of 6,7\% with a frequency of 2 persons.

In this study, 16 questions were put to 30 respondents regarding ideal indicators in the process of empowerment in the socio-economic field, after testing the validity of the questions the results obtained were 5 questions on the dimensions of skills transfer, 3 questions on the dimensions of inclusive service, 3 questions on the dimensions of supervision conducted by Amil, 3 questions about the dimensions of the communitybased and network-based program, and 2 questions about the dimensions of empowerment that give Islamic values can all be declared valid.

Reliability testing was conducted in this study using the Cronbach Alpha technique. The index is reliable if the coefficient of reliability is at least 0,60 (Siregar, 2015). The acquisition of the Cronbach Alpha value from the Socio-Economic Sector Empowerment Program Indicators is worth 0.803 , which means the questions raised to represent the variables in this study are reliable because they exceed the minimum value.

\section{Descriptive Analysis of Economic Empowerment Indicators}

Descriptive analysis results for the empowerment indicator according to the Transfer Skills dimension obtained the smallest value is 13 , the highest value is 25 , then the data obtained has an average value (M) of 19,97, the most total amount obtained from mustahik (Mode) is of 20, and the standard deviation (standard deviation) 2,988. Here are the scores for the Skills Transfer indicator:

Table 3 Frequency of Data Transfer Skills (skill)

\begin{tabular}{lccc}
\hline \multicolumn{1}{c}{ Category } & Total Value $(\mathrm{x})$ & Frequency & Percentage $(\%)$ \\
\hline Low & $\mathrm{x} \leq 19$ & 10 & 33,3 \\
Medium & $19 \leq \mathrm{x} \leq 22$ & 13 & 43,3 \\
High & $\mathrm{x}>22$ & 7 & 23,3 \\
\hline
\end{tabular}

From the score tabulation table 3 it can be seen that 7 mustahik respondents who participated in the economic empowerment program gave high scores on the related indicators of empowerment of the Skills Transfer dimension with a percentage of 23,3\%. 
Then as many as 13 respondents rated the Skill Transfer process provided by Amil as moderate with a percentage of $43,3 \%$, and 10 respondents rated the Skill Transfer process provided by Amil as less than optimal by giving a low category score of $33,3 \%$. Because respondents who answered the score were being more dominant, in general the empowerment program in the socio-economic field carried out by LAZISMU PDM Sleman took place the Skill Transfer process where the mustahik participants who were helpless were given some applied knowledge to carry out economic independence. In the goat development program in the Triharjo Village, Sleman, Amil provided material on livestock development by providing training in a period of time, even once a year Amil worked with a team of veterinarians to provide animal health education and it was hoped that participants would be able to care for livestock with well. However, this skill transfer process is not carried out in every program because some contracts regarding the empowerment of zakat funds are not all with qardlul hasan but not a few also with contracts in kind or in the form of production equipment compensation so that tends not to be carried out strictly advocacy, after compensation for production equipment Amil does not run various advanced programs.

In the empowerment indicator according to the Inclusive Service dimension, the smallest value is 8 , the highest value is 15 , then the average value $(\mathrm{M})$ obtained from the data is 12,50 , the highest total number obtained from the sample is 12 , and the standard deviation (standard deviation) has a value of 1,847 . Here are the scores:

Table 4 Frequency of Inklusive Services

\begin{tabular}{lccc}
\hline \multicolumn{1}{c}{ Category } & Total Value $(x)$ & Frequency & Percentage $(\%)$ \\
\hline Low & $x \leq 10,34$ & 4 & $13,3 \%$ \\
Medium & $10,34 \leq x \leq 12,56$ & 11 & $36,6 \%$ \\
High & $x>12,56$ & 15 & $50 \%$ \\
\hline
\end{tabular}

It is known that under 4 respondents namely mustahik who participated in the economic empowerment program gave a value to the empowerment process which tended to be low related to empowerment indicators in the Inclusive Services dimension with a percentage of $13,3 \%$. Then as many as 11 respondents rated the Inclusive Services dimension as moderate with a percentage of $36,6 \%$, and 15 respondents rated the Inclusive Services dimension as very good by giving a high category score with a percentage of $50 \%$.

Amil's services to Mustahik candidates or to participants in the empowerment program are very comprehensive, meaning that people belonging to the 8 asnaf members who are still listed as people within the scope of the PDM Sleman will be able to participate in the economic empowerment program. The process of absorption of mustahik was very diverse from all the findings during the program, starting with the mustahik recorded in the assembly notes, the mustahik who came to the officers and assemblies, and some mustahik recommended by muzakki. The absorption of mustahik and contract from distribution can be seen as inclusive services aimed at. Service inclusiveness is very evident when certain traders receive compensation for their business capital in the form of money or production equipment. For example, a juice seller in the Gamping area who 
was given two blender units because he asked for help from LAZISMU PCM then Amil gave the two blender units as venture capital with an In Kind contract, which means that the production equipment was given without imposing a mustahik to return Amil the value of the production equipment. The same happened to Mustahik, who earned compensation in the form of money with the mandate used as a business capital counter cell phone in the calcareous area with the same contract, given money with a value considered sufficient as capital to open up their business.

The results of the analysis of empowerment indicators according to the Supervision dimension given by Amil obtained the smallest value is 8 , the highest value is 15 , then the data collected has an average value (M) of 11,83, the total number that often appears is 12 , with deviations standard (standard deviation) which has a value of 1,859 . Based on the study results, the indicator value is:

Table 5 Frequency of Supervision by Amil

\begin{tabular}{lccc}
\hline \multicolumn{1}{c}{ Category } & Total Value $(x)$ & Frequency & Percentage (\%) \\
\hline Low & $x \leq 10,4$ & 7 & $23,3 \%$ \\
Medium & $10,4 \leq x \leq 12,6$ & 14 & $46,6 \%$ \\
High & $x>12,6$ & 9 & $30 \%$ \\
\hline
\end{tabular}

From the score tabulation, it is known that 7 respondents namely mustahik who participated in the economic empowerment program gave a value to the empowerment process which tended to be low related to empowerment indicators in the Supervision by Amil dimension with a percentage of $23,3 \%$. Then as many as 14 respondents rated the Supervision dimension to be moderate with a percentage of $46,6 \%$, and 9 respondents rated the Supervision dimension Provided by Amil to be classified as good by giving a high category score with a percentage of $30 \%$.

Supervision must continue because the purpose of this program is for Amil to be able to ensure that the Mustahik who becomes a participant in the economic empowerment program must be able to manage the business programmed by Amil independently. The majority of mustahik in this research are in the form of groups that are given special advocacy to manage the potential of a commodity, namely Goat Farmers by PCM Sleman and Fish Farmers by Lamping PCM. Mustahik who participates in the economic empowerment program in both groups is given advocacy or assistance periodically until he is able to manage independently. The oversight function is very important, in addition to the assistance function also for the control function of the allocation of funds in accordance with the program, because based on the explanation of the Chairperson of the LAZISMU Assembly PDM Sleman, not a few cases have occurred over the flight of funds by Mustahik due to lack of control. Finally, the expected goals of the empowerment program as well as the misuse of Islamic philanthropic funds were not achieved and this was a very fatal thing.

Descriptive analysis for empowerment indicators according to the Community and Network Based Empowerment dimensions obtained the smallest value is 6, the highest value is 15 , the average $(M)$ has a value of 10,63 , the total number that often appears 
(mode) is 12, and the standard deviation ( standard deviation) which has a value of 2,414. The indicator scores are as follows:

Table 6 Frequency of Community Based Empowerment and Networking

\begin{tabular}{lccc}
\hline \multicolumn{1}{c}{ Category } & Total Value $(x)$ & Frequency & Percentage $(\%)$ \\
\hline Low & $x \leq 9$ & 10 & $33,3 \%$ \\
Medium & $9 \leq x \leq 12$ & 17 & $56,6 \%$ \\
High & $x>12$ & 3 & $10 \%$ \\
\hline
\end{tabular}

From the score tabulation table 6 , it can be seen that 10 respondents namely mustahik who participated in the economic empowerment program gave a value to the empowerment process which tended to be low related to empowerment indicators in the Community and Network Based Empowerment dimension with a percentage of $33,3 \%$. Then as many as 17 respondents rated moderate with a percentage of $56,6 \%$, and 3 respondents rated the dimensions of Community-Based Empowerment and Network as quite good by giving a high category score with a percentage of $10 \%$.

An example is the Nogotirto Fish Market, supported by the coordinator of the Gamping PCM Economic Empowerment, that the backdrop to the growth of the Nogotirto Fish Market is the difficulties faced by fishermen in the Sleman area who have difficulty finding markets and adequate market prices. Fish that play the price and insights of fishermen who have not been able to determine the market price themselves so that the impact is not in line with the costs incurred by the benefits obtained by the fish farmers. Consequently, the empowerment activity provided provides insight into market price calculation which is a fish selling facility. Fish farmers are educated about how to farm fish, calculate the price per kilogram of fish and make the Nogotirto Fish Market a place to sell fish from farmers who previously sold to collectors who did not provide an honest and profitable sales system. But based on the acquisition of a low score given by 10 respondents, shows that indicators of community-based economic empowerment and networks have not been applied evenly, because there are still mustahik who develop individual businesses (not community-based) such as credit sellers, angkringan, or juice sellers whose empowerment models is In Kind provided with cash capital compensation or production equipment.

Descriptive analysis results for empowerment indicators according to the dimensions of giving Islamic values obtained the smallest value is 6 , the highest value is 10 , the average (M) has a value of 8,67 , the total number that often appears is 8 , with a standard deviation (standard deviation ) which has a value of 1,093 . Then based on the results of the study, here are the scores for the empowerment indicators according to the dimensions of giving Islamic values:

Table 7 Frequency of Giving Islamic Values

\begin{tabular}{lccc}
\hline \multicolumn{1}{c}{ category } & Total Value $(x)$ & Frequency & Percentage (\%) \\
\hline Low & $x \leq 8,7$ & 17 & $56,6 \%$ \\
Medium & $8,7 \leq x \leq 9,3$ & 3 & $10 \%$ \\
High & $x>9,3$ & 10 & $33,3 \%$ \\
\hline
\end{tabular}


Based on the tabulation of the score, as many as 17 respondents namely mustahik who participated in the economic empowerment program gave a value to the empowerment process which tended to be low related to empowerment indicators in the dimension of giving Islamic values a percentage of $56,6 \%$. Then as many as 3 respondents rated moderate with a percentage of $10 \%$, and 10 respondents rated the dimensions of giving Islamic values classified as good by giving a high category score with a percentage of $20 \%$.

\section{Program Empowerment Utilization Analysis}

Based on the results of statistical tests it was found that the program significantly influences where mustahik obtain independence in the field of business following the economic empowerment program. In general, based on the results of interviews with several LAZISMU staff at the PDM and PCM levels, the most important hope from the implementation of economic empowerment is that mustahik who become program participants who are not yet independent receive business independence. Findings in the Triharjo Village, Sleman, that before participating in the empowerment program the majority of participants worked as casual laborers and did not have skills in other fields, therefore amil provided a business capital of a pair of goats as a form of venture capital and then the participants were given education about the livestock business participants can be said to be independent in managing it.

The second dimension of the benefit analysis concerns the improvement of the Mustahik's economic conditions. From the results of testing the hypothesis where $\mathrm{HO}$ is rejected and $\mathrm{H} 1$ is accepted, it means that most of the mustahik who are participants of the LAZISMU PDM Sleman economic empowerment program have experienced improvements in terms of economic conditions. In addition to answers to the questionnaire and information from informants, there were also many findings in the field that indicated the improvement in the economic conditions of the program participants, for example, the price of fish from farmers in the Nogotirto Fish Market. After the Nogotirto Fish Market was provided, the fish farmers there received better income than before distributing it to the fish market, the appropriate price and certainty of the distribution of fish sales made the commodity produced by the farmers sold and provided decent profits that could even be said to be maximum. Unlike the conditions in the Nogotirto Fish Market, the goat breeders in Triharjo, Sleman, although not immediately obtaining market certainty, the goat breeders have improved economic conditions by obtaining additional business assets in the form of livestock, and these animals have high asset values and are better than assets owned by fish farmers, then the urgency there, just how to manage livestock that is good, healthy, and has a maximum sale value so that the cattle become a new source of income for the mustahik who previously earned income from services as a freelance worker.

The first dimension of benefit analysis is regarding the community and business networks of the mustahik. From the results of testing the hypothesis where $\mathrm{HO}$ is rejected and $\mathrm{H} 1$ is accepted, it means that most of the mustahik who are participants of the LAZISMU PDM Sleman economic empowerment program are classified as already 
having communities and networks in the business sector. The findings obtained by researchers in the field, the community formed by the existence of an empowerment program is not in the form of a standard community, meaning that it is not formed by a formal community but that the participants are engaged in the same business line and are collectively managed and have the same business network. Fish farmers who distribute their goods at the Nogotirto Fish Market prior to being given advocacy by Amil, indeed the fish farming community has been formed but is only constrained by marketing post-harvest fish commodities and Amil helps in developing the management of the fish market into a facility that houses fish farmers by forming a system advantageous, an updated system is the provision of education to fish farmers regarding the determination of the market price of fish commodities to collectors and providing market guarantees to farmers so that farmers do not have difficulty in selling distribution.

\section{Analysis of The Economic Conditions Changes}

The social-economic empowerment program implemented by LAZISMU PDM Sleman has made changes to the economic conditions of mustahik participants, the majority of which have experienced changes based on income or the addition of business assets owned, and some respondents have not yet received additional income or added business assets.

\section{Conclusion}

Based on the results of the analysis and discussion of the research carried out by LAZISMU PDM Sleman on the Community Empowerment in the Economy Programme, the empowerment program takes place in the process of skill transfer in which Mustahik participants who have not been empowered are given the knowledge they need to carry out economic independence. For Amil services to Mustahik candidates or empowerment program participants are very inclusive, meaning that people included in the 8 asnaf who are still classified as people within the reach of PDM Sleman will be given the convenience of participating in economic empowerment programs. LAZISMU also acted as a program supervisor in the form of community and individual mustahik. Meanwhile, community empowerment in the economic field conducted by LAZISMU PDM Sleman has already formed several communities in the business sector, while other communities are greatly helped by the establishment of business networks, while community empowerment provides Islamic values that are not so significant.

Most of the Mustahik people who participate in the LAZISMU PDM Sleman economic empowerment system are rated as autonomous in the programmed business sector, have undergone economic changes, and already have communities and networks in the business sector. 


\section{References}

Abidin, Z. (2013). Manifestasi dan Latensi Lembaga Filantropi Islam dalam Praktik Pemberdayaan Masyarakat: Suatu studi di Rumah Zakat Kota Malang. Jurnal Salam 15(2), 197-214. Retrieved from http://ejournal.umm.ac.id/index.php/salam/article/view/1630

Andini, S. N. M., (2011). Pengelolaan Dana Qardul Hasan terhadap Pemberdayaan Masyarakat Kampung Sukamulya : Studi Kasus Dana Qardul Hasan pada BAZ Kota Bogor. Skripsi. Jakarta: Universitas Islam Negeri Jakarta.

Antonio, M. S. (1999). Bank Syariah : Wacana Ulama \& Cendekiawan. Jakarta : Islamic Bank dan Tazkia Institute.

Ascarya. (2008). Akad \& produk Bank Syariah. Jakarta : PT. Raja Gravindo.

Ash Shadr, M. B. (2008). Our Economics, edisi terj: Buku Induk. Ekonomi Islam : Iqtishaduna. Cet-1. Jakarta: Zahra.

Ash-Shiddieqy, T. M. H. (2009). Pedoman Zakat. Cet-2. Semarang : Pustaka Rizki Putra.

Azwar, S. (2012). Metode Penelitian. Yogyakarta : Pustaka Pelajar.

Djawanto. (2003). Statistik Non Parametrik. Yogyakarta : BPFE.

Hafidhudi, D. (1998). Panduan Praktis tentang Zakat Infak Sedekah. Jakarta: Gema Insani Press.

Hasanah, U. (2014). Zakah Management in Saudi Arabia, Sudan and Indonesia. The Indonesian Management \& Accounting Research (IMAR), 13(1), 40-61. http://dx.doi.org/10.25105/imar.v13i1.1163

Ife, J., \& Tesorieso, F. (2008). Alternatif Pengembangan Masyarakat di Era globalisasi, Penerjemab: Sastrawan Manullang dkk, Yogyakarta: Pustaka Pelajar.

Jogiyanto. (2004) Metodologi Penelitian Bisnis : Salah kaprah dan Pengalaman-Pengalaman. Yogyakarta : BPFE.

Karim, A. A., (2010). Sejarah Pemikiran Ekonomi Islam. Ed. 3, 4. Jakarta ; Rajawali Pres.

Kholis, N., Sobaya, S., Andriansyah, Y., \& Iqbal, M., (2014). Potret Filantropi Islam di Propinsi Daerah Istimewa Yogyakarta. La_Riba, 7(1), 61-84. Retrieved from https://mpra.ub.uni-muenchen.de/58599/

Korten, D. C., (1984). Pembangunan yang Memibak Rakyat. Jakarta : Yayasan Studi Pembangunan.

Latief, H. (2013). Politik Filantropi Islam di Indonesia. Yogyakarta: Penerbit Ombak.

LAZISMU PCM Sleman. (2017). Laporan Pengelolaan Zakat, Infaq, \& Shadaqob Periode XIII (Tiga Belas) Tabun, 1437 H / 2016 M. Yogyakarta : LAZISMU PCM Sleman.

LAZISMU, EPI UMY, LP3M UMY. (2015). Perilaku dan Potensi Filantropi Warga Muhammadiyah (Survei di 11 Kota Besar di Indonesia. Yogyakarta.

Martono, N. (2010). Statistika Sosial: Teori dan Aplikasi Program SPSS. Yogyakarta: Penerbit Gava Media.

Mubasirun. (2013). Distribusi Zakat dan Pemberdayaan Ekonomi Umat. INFERENSI, Jurnal Penelitian Sosial Keagamaan, 7(2), Desember. https://doi.org/10.18326/infsl3.v7i2.493-512

Mubyarto. (2000). Membangun Sistem Ekonomi, Cet-1. Yogyakarta: BPFE.

Nasution, (2008). Indonesia Zakat and Development Report. Depok: CID.

Pimpinan Pusat Muhammadiyah. (2017). Pedoman Pimpinan Pusat Mubammadiyah Tentang LAZISMU. Yogyakarta : PP Muhammadiyah.

Qardhawi, Y. (2002). Musykilat al-Faqr wa Kaifa 'Alajaha al-Islam, edisi terj: Teologi Kemiskinan : Doktrin Dasar dan Solusi Islam atas Problem Kemiskinan. Cet-1. Yogyakarta : Pustaka Pelajar Offset.

Ridho, M. T. (2006). Pengelolaan Zakat di Negara-negara Islam, dalam Afiah, K, $N$ dan Tajang, $M$, N, Zakat dan Peran Negara. Jakarta; Forum Zakat. 
Ridwan, M. (2013). Analisis Pengelolaan Program Zakat Produktif pada Lembaga Amil

Zakat BAPELURZAM, Gamping, Sleman, Yogyakarta. (Doctoral dissertation, FAI $U M Y)$.

Sanrego, Y. D., \& Taufik, M. (2016). Fiqib Tamkin: Fiqib Pemberdayaan: Membangun Modal Sosial dalam Mewujudkan Khairu Ummah. Jakarta : Qisthi Press.

Soeratno, M. E. (2014). Operational Evaluation of Zakat Distribution Formed in the Micro-

Economic Empowerment Program in Sleman, Bantul, and Gunungkidul, 2013-2014

Case Study: SAKOFA Program of Dompet Dhuafa Yogyakarta. Doctoral dissertation, Universitas Gadjah Mada.

Soetomo. (2013). Pemberdayaan Masyarakat: Mungkinkah Muncul Antitesisnya?. Cet-2.

Yogyakarta : Pelajar Pustaka

Sugiono. (2001). Satatistik Nonparametris: Untuk Pen.elitian. Cet-2. Bandung: Alfabeta.

Suharto, Edi. (2003). Membangun Masyarakat Memberdayakan Rakyat : Kajian Strategis

Kesejabteraan dan Pekerjaan Sosial. Cet-1. Bandung : PT Refika Aditama,

Supranto, J. (2001). Statistik: Teori dan Aplikeasi, Jilid-2. Jakarta : Erlangga.

Uphoff, N. (1986). Local Institutional Development, Kumarian Press, Westhartford, Connecticut.

Winardi. (2000). Pengantar Imu Ekonomi. Bandung : Tarsito

Yuliadi, I. (2001). Ekonomi Islam Sebuah Pengantar. Cet-1. Yogyakarta Pustaka Pelajar Offset.

Yusoff, M. (2011). Zakat Expenditure, School Enrollment, and Economic Growth in Malaysia. International Journal of Business and Social Science, 2(6), 175-181. Retrieved from http://www.ijbssnet.com/archive/277.html 